\title{
Ciri-Ciri Tipe Negara Yunani Purba dan Eksistensinya
}

\author{
Miftahul Janah \\ Email: miftahul8072003@gmail.com
}

No. BP: 2110003600102

UNIVERSITAS EKASAKTI

\section{A.PENDAHULUAN}

Sejarah telah mencatat bahwa setiap zaman mempuyai pemikiran-pemikiran Yang berbeda dan tokoh-tokoh yang berbeda mengenai cerita ketatanegaraan, Ketika kita berbicara pada ranah kenegaraan yang perlu kita ketahui adalah Bagaimana menjadikan masyarakat sejahtera dan makmur, tanpa melepaskan sendi-sendi keutamaan sebuah negara itu berdiri, dan seperti yang kita ketahui Ketika para pendiri bangsa ( The founding fathers) mendesain model negara Indonesia setelah merdeka lebih mengedepankan perdebatan mengenai dasar negara, bentuk negara (kesatuan atau federal), bentuk pemerintahan (kerajaan atau republik) dan ide/cita negara yang sedikit terkait dengan negara hukum dan pemerintahan yang demokrasi semua itu adalah persyaratan yang urgen dalam sebuah pembangunan negara dan menjadikan negara itu jelas dari tipe sejarah maupun dari kacamata hukum.

Selain perkembangan masyarakat setara, masyarakat bertingkat dan masyarakat berlapis, masih ada faktor-faktor lain yang melandasi perkembangan dari pemerintahan. Pertambahan dan/atau tekanan penduduk, perang atau ancaman perang dan penjarahan oleh kelompok lain telah menjadi faktor-faktor yang memacu perkembangan pemerintahan yaitu penguasaan oleh suatu pemerintah atau negara. Kelebihan produksi dan penciptaan, kewajiban atas dasar timbal balik merupakan cara-car a untuk mendapatkan kekuasaan atas sesame manusia atau 
kelompok masyarakat. Pihak yang memerintahkan menawarkan perlindungan hukum, kesejahteraan dan menyajikan kesentosaan bagi pihak yang diperintah.

Sejarah menunjukkan bahwa manusia telah diperintah oleh tak terbilang sistem pemerintahan. Ada system pemerintahan bangsa-bangsa Inka dan Aztek, system kerajaan Mesir dan Babilonia Purba, kerajaan-kerajaan Persia beragam, negara kota bangsa Romawi dan Yunani, kerajaan Bizantium, negara-negara Hindu Kuno dan Kerajaan Moghul, kalifah Arabia dan negara muslim. Ada sistem pemerintahan Eropa sejak keruntuhan sistem feudal sampai kepada abad absolutisme dan kemudian sistem-sistem pemerintahan kolonial.

Seperti yang diteorikan oleh George Jellinek dan Jean Bodin bahwa negara Itu berdaulat yang dimana hukum ada karena adanya negara dan tiada satupun Hukum yang berlaku jika tidak diketahui oleh negara. Dari teori tersebut kita bisa mengulas sebuah konsep bahwa negara itu adalah system yang betul-betul berkuasa terhadap kehidupan seluruh yang ada didalamnya demi mensejahterakan rakyatny a. negara terbentuk atas dasar pemikiran manusia seperti George JellenikJean Bodin, Rousseau, Diguit, Krabbe dan pemikir-pemikir lainnya, bahkan beberapa filosof membuat konsep kemasyarakatan seperti Thales, Socrates, Plato,Aristoteles, dan lain-lain. Dinilai dari segi sejarah konsep ketatanegaraan bermacam-macam ragam dan tipe pemerintahannya, maka dari itu makalah ini dibuat guna mempelajari tipe-tipe negara pada masa Yunani purba dilihat dari segi sejarahnya.

\section{B.PEMBAHASAN}

1. Pengertian Tipe-Tipe Negara

Menurut, R.D joko Soetono : Negara adalah suatu organisasi atau asosiasi wilayah yang memiliki kekuatan individu dan daerah yang 
mengatur setiap kumpulan manusia -manusia yang berbeda dibawah suatu pemerintahan yang sama dengan terapan sistem hukum.

Bentuk atau Tipe negara adalah merupakan batas antara peninjauan Secara sosiologis dan peninjauan secara yuridis mengenai negara. Peninjauan secara sosiologis jika negara dilihat secara keseluruhan (ganzhit) tanpa melihat strukturnya, sedangkan secara yuridis jika negaralpeninjauan dilihat dari strukturnya.

Machiavellii dalam bukunya II Prinsipe bahwa bentuk negara (hanya ada dua pilihan) jika tidak republik tentulah Monarkhi. Selanjutnya menjelaskan negara sebagai bentuk genus sedangkan Monarkhi dan republik sebagai bentuk species nya.

Perbedaan dalam kedua bentuk Monarkhi dan republik (J ellinek, dalam bukunya Allgemene staat lehre) didasarkan atas perbedaan proses terjadinya pembentukan kemauan negara itu terdapat dua kemungkinan:

1.Apabila cara terjadinya pembentukan kemauan negara secara psikologis atau secara alamiah, yang terjadi dalam jiw a/badan seseorang dan nampak sebagai kemauan seseorang/individu maka bentuk negaranya adalah Monarhki.

2.Apabila cara pros es terjadinya pembentukan negara secara yuridis, secara sengaja dibuat menurut kemauan orang banyak sehingga kemauan itu nampak sebagai kemauan suatu dewan maka bentuk negaranya adalah republik.

\section{Sifat Khusus Negara}

Sifat khusus yang harus dimiliki dari pada suatu negara ada tiga (3) 
yaitu sebagai berikut :

a.Memaksa

Sifat memaksa perlu dimiliki oleh suatu negara-negara, agar peraturan perundang- undangan ditaati sehingga penertiban dalam masyarakat dapat dicapai.

b.Monopoli

Negara mempunyai monopoli dalam menetapkan tujuan bersama dari masyarakat, negara berhak melarang suatu aliran aliran kepercayaan atau aliran politik tertentu hidup dan diserba luaskan kalau dianggap bertentangan dengan tujuan masyarakat.

c.Mencakup secara keseluruhan

Semua peraturan perundang-undangan berlaku untuk seluruh masyrakatnya.

Tipe Negara Yunani kuno/Purba

Tipe Negara yunani kuno ini bersifat Aristokrasi, pemerintahan oleh aristokrat (cendikiawan), tipe ini mempunyai bentuk negara kota (city state) negaranya kecil hanya satu kota saja dan dilingkari oleh benteng pertahanan dan penduduknya sedikit, Pemerintahannya bersifat demokrasi Demokrasi langsung (musyawarah). Dalam Pelaksanaan demokrasi langsung rakyat diberikan ilmu pengetahuan oleh aris tokrat atau filosof (cendikiawan) tentang cara menjalankan pemerintahan mereka. Jika menjalankan pemerintahannya biasanya rakyat berkumpul disuatu tempat (acclesia) untuk membuat suatu keputusan(musyawarah).

Ciri utama Negara yunani kuno adalah Negara kota dan demokrasi 
langsung. Ini berdas arkan pemikiran para filsuf bahwa manusia adalah zoon politicon sehingga mereka merasa bahwa tidak ada gunanya jika tidak hidup bermasyarakat. Tidak hanya itu mereka juga mengutamakan status activus yaitu aktif terlibat dalam urusan pemerintahan, dengan demikian maka munculah demokrasi langsung di yunani. Demkrasi langsung dapat muncul di yunani disebabkan karena:

1.Yunani pada waktu itu masih merupakan Negara kota

2.Persoalan dalam Negara belum terlalu kompleks dan septiap warga Negara adalah minded

Meskipun demikian demokrasi langsung yang terjadi di yunani adalah tidak murni hal ini disebabkan karena di yunani terdapat 3 golongan penduduk yaitu: golongan penduduk asli, golongan orang pandatang, golonagan budak. Sedangkan yang ikut dalam pemerintahan hanyalah golongan penduduk asli sebab golongan pendatang dan budak bukanlah merupakan subyek hukum yang dapat memiliki hak.

Bentuk penyelenggaraan negara, yaitu demokrai langsung (ex: referendum). Kebiasaan orang Yunani kuno adalah membicarakan berbagai persoalan hidup, termasuk politik dan negara. Hal ini karena ada beberapa faktor: pertama, negara sering mengalami pertukaran pemerintahan, dari monarki ke aristokrasi, dari aristokrasi ketirani, dari tirani ke demokrasi; kedua, adanya kebebasan bicara; ketiga, negara disamankan dengan masyarakat, dan juga sebaliknya; keempat, cara hidup yg selalu memperhatlihatkan dan 
mendiskusikan masalah secara bersama

Tipe Negara yang Ditinjau dari Sisi Hukum

Tipe negara yang ditinjau dari sisi hukum adalah penggolongan negara- negara dengan melihat hubungan antara penguasa dan rakyat.

Terdapat dua

A .Tipe Negara Polisi (Polisi Staat)

Sejarah "Negara polisi" istilah pertama kali digunakan pada tahun 1851, mengacu pada penggunaan kekuatan polisi nasional untuk menjaga ketertiban, di Austria. Pada kenyataannya, bahkan pada tingkat lokal, penggunaan kekuatan polisi untuk secara aktif menjaga ketertiban, di luar keadaan darurat, hampir tidak dikenal sebelum waktu ini.

Penggunaan pertama dari kepolisian negara bagian di AS, misalnya, adalah tahun yang sama, 1865, di mana kekuatan semacam didirikan di $\mathrm{M}$ assachusetts .Sampai saat ini, tatanan masyarakat yang paling dipertahankan secara spontan, pada tingkat lokal, dengan beberapa kepolisian lemah seperti seorang sheriff yang dipanggil ke tindakan untuk insiden tertentu Sebagai pemeliharaan kekuatan polisi berdiri menjadi umum di akhir abad 20 dan awal ke-19, istilah "negara polisi” datang yang akan digunakan lebih umum untuk merujuk hanya ketika kekuatan polisi digunakan "terlalu" keras, dalam "kaku dan represif "cara, seperti di bawah fasisme, komunisme, kapitalisme dan dalam aplikasi retroaktif insiden bersejarah yang menindas / represif seperti Revolusi Perancis dan Kekaisaran Romawi 
Pada tipe ini negara bertugas menjaga tata tertib saja atau dengan kata lain negara jaga malam. Pemerintah bersifat monarki absolut. Pengertian polisi adalah welvaartzorg, (penyelenggaraan kes ejahteraan) yang mencakup dua arti:

1.Penyelenggaraan Negara positif (Bes tuur)

2.Penyelenggaraan Negara negative (Menolak bahaya yang mengancam Negara atau keamanan)

Negara Jaga Malam adalah kata yang tepat untuk menggambarkan tipe negara ini, yakni sebuah negara yang yang menyelenggarakan keamanan dan kemakmuran dalam bidang ekonomi. Slogan yang dipakai dalam negara yang bertipe sebagai polisi ini adalah "Sallus Publica Supreme Lex" (kepentingan umum sebagai yang harus diutamakan).D an hanya rajalah yang mengkategorikan mana kepentingan umum dan mana yang bukan, dengan kata lain "Letat cesst moi”, yang berarti negara adalah aku (raja).

Sebuah negara polisi adalah satu di mana pemerintah latihan kontrol kaku dan represif terhadap kehidupan sosial, ekonomi dan politik dari populasi. Sebuah negara polisi biasanya pemeran unsur totalitarianisme dan kontrol sosial, dan biasanya ada sedikit perbedaan atau tidak antara hukum dan pelaks anaan kekuasaan politik oleh eksekutif.

Penduduk dari suatu pembatasan polisi negara pengalaman mobilitas mereka, dan kebebasan mereka untuk mengekspresikan atau mengkomunikasikan pandangan politik atau lainnya, yang tunduk pada pengawasan polisi atau penegak. Kontrol politik dapat 
diberikan dengan cara kekuatan polisi rahasia yang beroperasi di luar batas normal yang dikenakan oleh Negara hukum.

Praktek dan pemikiran kenegaraan Inggris adalah sebagai contohnya, yang mana kekuasaan absolut raja- raja semuanya . bersandar pada tipe Negara polisi. Seluruh penyelenggaraan negara dipegang penuh oleh raja, atau setidaknya diselenggarakan dengan bantuan lembaga bawahannya atas perintah raja. Dan apabila penyelenggaraan kemakmuran dilaksanakan oleh negara, maka keresahan rakyat tidak bisa dielakkan, karena rakyat merasa dirugikan.

a)Klasifikasi Negara polisi

Klasifikasi negara atau rezim sebagai negara polisi biasanya diperebutkan dan diperdebatkan. Karena konotasi istilah merendahkan, sangat jarang bahwa suatu negara akan mengidentifikasikan dirinya sebagai negara polisi. Ada beberapa organisasi non-pemerintah yang menerbitkan dan mempertahankan penilaian negara kebebasan di dunia, sesuai dengan definisi mereka sendiri berbagai istilah, dan negara- negara peringkat sebagai bebas, sebagai bebas, atau tidak bebas menggunakan berbagai ukuran kebebasan, termasuk hak politik, hak ekonomi, dan kebebasan sipil Penggunaan istilah ini termotivasi sebagai respon terhadap, kebijakan hukum dan tindakan rezim itu, dan sering digunakan untuk menggambarkan pengertian yang merendahkan konsep rezim dari kontrak sosial, hak asasi manusia, dan hal- hal serupa 
bangsa tersebut telah menjadi, atau menjadi, sebuah negara polisi. Karena ada perspektif politik yang berbeda seperti apa keseimbangan yang tepat antara kebebasan individu dan keamanan nasional, tidak ada standar objektif definitif untuk menentukan apakah istilah "negara polisi" berlaku untuk suatu bangsa tertentu pada titik waktu tertentu. Jadi, Sulit untuk dinilai secara obyektif kebenaran tuduhan bahwa bangsa adalah, atau tidak menjadi, sebuah negara polisi. Salah satu cara untuk melihat konsep negara polisi dan negara bebas adalah melalui medium atau skala keseimbangan, di mana hukum yang berfokus pada menghilangkan kebebasan dipandang sebagai bergerak menuju sebuah negara polisi, dan hukum yang membatasi pengawasan pemerintah dipandang Negara polisI Asli pada das arnya otoriter, dan sering kediktatoran. Namun tingkat represi pemerintah bervariasi secara luas di antara masyarakat. Rezim paling jatuh ke beberapa jalan tengah antara ekstrem dari libertarianisme sipil dan totalitalitarisme.

D i bawah model politik absolutisme tercerahkan, penguasa adalah "hamba negara yang tertinggi" dan latihan kekuasaan absolut untuk menyediakan kesejateraan umum penduduk. Model pemerintahan mengusulkan bahwa semua kekuasaan negara harus diarahkan ke arah tujuan ini, dan menolak kodifikasi, kendala hukum pada kekuasaan mutlak penguasa. Pemikir seperti Thomas Hobbes mendukung jenis pemerint ahan absolut. Sebagai penguasa, tercerahkan mutlak dikatakan dibebankan dengan kepentingan publik, dan secara implisit sempurna atas hak pengangkatan, bahkan 
kritis, oposisi loyal kepada partai penguasa adalah kejahatan terhadap negara.

Konsep oposisi loyal tidak sesuai dengan politik. Seperti perbedaan pendapat publik dilarang, itu pasti menjadi rahasia, yang, pada gilirannya, adalah balas dengan represi politik melalui polisi rahasia. Demokrasi liberal, yang menekankan aturan hukum, berfokus pada negara polisi tidak menjadi subjek hukum. Robert von Monhl, yang pertama kali memperkenalkan aturan hukum untuk yuris prudensi Jerman, mengontraskan Rechtsstaat "hukum" atau "konstitusional" Dalam masa darurat nasional atau perang, saldo yang biasanya mungkin ada di antara kebebasan dan keamanan Perang sering digambarkan dalam fiksi sebagai pendahulu yang sempurna untuk mendirikan sebuah negara polisi, sebagai warga negara yang lebih tergantung pada pemerintah mereka dan polisi untuk keamanan dari biasanya (lihat negara polisi fiksi di bawah). Sebuah negara polisi elektronik adalah satu di mana pemerintah secara agresif menggunakan teknologi elektronik untuk merekam, mengatur, mencari dan mendis tribus ikan bukti forens ik terhadap warganya. Sebuah "polisi negara sementara" bisa eksis dengan desain. Sebagai contoh, di Kopenhagen tahun 2009, pemerintah Denmark diberlakukan undang-undang yang akan mengizinkan polisi untuk menggunakan kebijaks anaan tak terbatas dalam menahan mereka yang diduga polis $\mathrm{i}$ menentang $\mathrm{K}$ onferens i $\mathrm{P}$ ara $\mathrm{P}$ ihak pada $\mathrm{K}$ onvens $\mathrm{i}$ Kerangka kerja PBB tentang Perubahan Iklim. Undang- undang berisi kadaluarsa, tetapi otoritas polisi selama Konferensi para Pihak adalah dicentang. 
b)Tercerahkan absolutisme negara dengan Polizeis t aat aris tokrat ("negara polis i").

c)Contoh Negara polisi seperti atribut

Seperti dibahas sebelumnya, tidak mungkin untuk obyektif

menentukan apakah sebuah bangsa telah menjadi atau menjadi

negara polisi. Sebagai akibatnya, untuk menyusun daftar lengkap

dari polisi negara akan inheren cacat. Namun, ada beberapa contoh

yang sangat diperdebatkan berfungsi untuk menggambarkan

karakteristik parsial struktur sebuah negara polisi. Contoh-contoh

ini tercantum di bawah ini.

Sistem apartheid Afrika Selatan pada umumnya dianggap telah

menjadi negara polisi meskipun telah nominal demokrasi (meskipun

dengan mayoritas penduduk Afrika Hitam di kecualikan dari

demokrasi).

UniSoviet dan negara banyak satelit, termasuk Korea Utara dan

Jerman Timur yang terkenal karena polisi mereka luas dan represif

dan intelijen, dengan sekitar 2,5\% dari populasi orang dewasa

Jerman Timur melayani (sadar atau tidak sadar) sebagai informan

Stasi. Nazi Jerman, kediktatoran, adalah, setidaknya pada awalnya,

terwujud melalui demokrasi nominal, namun diberikan kontrol

represif terhadap rakyatnya.

Di Kuba, 22 wartawan yang mencoba untuk mempublikasikan berita non-pemerintah yang berwenang tetap dipenjarakan. Ditangkap pada Maret 2003, para wartawan melayani hukuman penjara hingga 27 tahun. Hal ini juga melaporkan bahwa wartawan tidak di penjara sering terancam dengan nasib yang sama. Yang berbasis di Paris 
Wartawan Tanpa Batas peringkat Utara keluar Korea terakhir kedua dari 168 negara dalam tes kebebasan pers. Telah dilaporkan bahwa saluran TV hanya di Korea Utara didominasi eulogises pemimpin saat ini negara itu Kim Jong il dan ayahnya (dan pemimpin sebelumnya) Kim Il Sung. Akibatnya, beberapa penduduk setempat di Pyongyang telah dikutip sebagai menyatakan bahwa pemimpin mereka adalah dewa.

Adapun juga Negara yang akan menuju pada tipe Negara ini. Dimana negara bertugas menjaga tata tertib saja atau dengan kata lain negara jaga malam. Sebagai contoh: Negara Australia, tepatnya . Australia bagian barat, parlemen negara bagian saat ini Mengusulkan baru "berhenti dan cari” undang- undang yang telah dikritik sebagai langkah menuju sebuah negara polisi. Undangundang baru yang diusulkan memberikan kepada polisi Australia Barat hak untuk melakukan pencarian tanpa surat perintah atau alasan kecurigaan. Undang-undang tersebut ditolak oleh sebuah komite parlemen pada bulan Oktober 2010, namun Perdana Menteri Australia Barat Colin Barnett telah menyatakan bahwa ia masih akan mendorong undang- undang dengan beberapa perubahan. b.Tipe Negara Hukum (Rechts staat)

Tipe Negara yang ditinjau dari sisi hokum adalah penggolongan Negara - Negara dengan melihat hubungan antara penguasa dan rakyat. Negara hokum timbul sebagai reaksi terhadap kekuasan raja- raja absolute. Ada tiga tipe Negara hokum, yaitu:

1.Tipe Negara hokum liberal 
Tipe Negara hokum liberal ini menghendaki supaya negara berstatus pasif, artinya bahwa warga Negara harus tunduk pada peraturan peraturan Negara. Penguasa dalam bertindak sesuai dengan hokum. Disini kaum liberal menghendaki agar penguasa dan yang dikuasai ada suatu persetujuan dalam bentuk hokum, serta persetujuan yang menjadi penguasa.

Contoh Negara yang memakai tipe Negara hokum liberal:

a)Negara- negara yang menganut paham liberal di benua Amerika adalah Amerika Serikat, Argentina, Bolivia, Brazil, Cili, Cuba, Kolombia, Ekuador, Honduras, Kanada, Meksiko, Nikaragua, Panama, Paraguay, Peru, Uruguay dan Venezuela. Sekarang ini, kurang lebih liberalisme juga danut oleh negara Aruba, Bahamas, Republik Dominika, Greenland, Grenada, Kosta Rika, Puerto Rico dan Suriname.

b) Negara- negara penganut paham liberal di Eropa yakni diantaranya adalah Albania, Armenia, Austria, Belgia, Bulgaria, Kroas ia, Cyprus, Republik Cekos lovakia, Denmark, Estonia, Finlandia, Perancis, Jerman, Yunani, Hungaria, Islandia, Italia, Latvia, Lithuania, Luxembourg, Macedonia, Moldova, Netherlands, Norwegia, Polandia, Portugal, Romania, Rusia, Serbia Montenegro, Slovakia, Slovenia, Spanyol, Swedia, Switzerland, Ukraina dan United Kingdom. Negara penganut paham liberal lainnya adalah Andorra, Belarusia, Bosnia-Herzegovina, Kepulauan Faroe, Georgia,Irlandia dan San Marino.

c)Negara- negara yang menganut paham liberal di Asia antara lain adalah India, Iran, Israel, Jepang, Korea Selatan, Filipina, Taiwan, 
Thailand dan Turki. Saat ini banyak negara- negara di Asia yang mulai berpaham liberal, antara lain adalah Myanmar, Kamboja, HongKong, Malaysia dan Singapura.

d)Negara yang menganut paham liberal di kepulauan Oceania adalah Australia dan Selandia Baru.

e)Sistem ekonomi liberal terbilang masih baru di Afrika. Pada dasarnya, liberalisme hanya dianut oleh mereka yang tinggal di Mesir, Senegal dan Afrika Selatan. Sekarang ini, kurang lebih liberalisme sudah dipahami oleh negara Aljazair, Angola, Benin, Burkina Faso, Mantol Verde, Côte D 'Ivoire, Equatorial Guinea, Gambia, Ghana, Kenya, Malawi, Maroko, Mozambik, Seychelles, Tanzania, Tunisia, Zambia dan Zimbab e

\section{Tipe Negara hokum formil}

Negara hukum formil yaitu negara hukum yang mendapat penges ahan dari rakyat, segala tindakan penguasa memerlukan bentuk hukum tertentu, harus berdasarkan undang- undang. Negara hukum formil ini disebut pula dengan negara demokratis yang berlandas kan negara hukum. Dalam hal ini menurut Stahl seorang sarjana Denmark maka negara hukum formil itu harus memenuhi empat unsur:

a) Bahwa harus adanya jaminan terhadap hak-hak asasi.

b)Adanya pemisahan kekuasaan.

c)Pemerintahan didasarkan pada undang-undang.

d)Harus ada peradilan administrasi.

Contoh Negara demokratis adalah Negara Indonesia 
3Tipe Negara hokum materiil

Negara hokum materiil sebenarnya merupakan perkembangan lebih lanjut dari Negara hokum formil, tindakan penguasa harus

berdasarkan undang - undang atau berlaku asas legalitas, maka dalam Negara hokum materiil tindakan dari penguasa dalam hal mendesak demi kepentingan warga Negara dibenarkan bertindak menyimpang dari undang - undang atau berlaku asas opportunitas .

c.Negara Hukum Anglo Saxon (Rule Of Law )

Negara anglos axon tidak mengenal negara hokum atau rechts taat, tetapi mengenal atau menganut apa yang disebut dengan "The Rule O f The Law" atau pemerintahan oleh hokum atau government of judiciary. Menurut Kansil, prinsip Rule of Law pada umumnya mendasarkan pada:

\section{Supremacy Of Law}

Dalam suatu Negara hukum, maka kedudukan hukum merupakan posisi tertinggi, kekuasaan harus tunduk pada hukum bukan sebaliknya hukum tunduk pada kekuasaan, bila hukum tunduk pada kekuasaan, maka kekuasaan dapat membatalkan hukum, dengan kata lain hukum dijadikan alat untuk membenarkan kekuasaan. Hukum harus menjadi "tujuan" untuk melindungi kepentingan rakyat.

2.Equality Before The Law

Dalam suatu Negara hukum, maka kedudukan hukum merupakan posisi tertinggi, kekuasaan harus tunduk pada hukum bukan sebaliknya hukum tunduk pada kekuasaan, bila hukum tunduk pada kekuasaan, maka kekuasaan dapat membatalkan hukum, dengan kata lain hukum dijadikan alat untuk membenarkan kekuasaan. Hukum 
harus menjadi "tujuan" untuk melindungi kepentingan rakyat.

2.Equality Before The Law

Dalam Negara hukum kedudukan penguasa dengan rakyat dimata hukum adalah sama (sederajat), yang membedakan hanyalah fungsingnya, yakni pemerintah berfungsi mengatur dan rakyat yang diatur. Baik yang mengatur maupun yang diatur pedomannya satu, yaitu undang-undang. Bila tidak ada persamaan hukum, maka orang yang mempunyai kekuasaan akan merasa kebal hukum.

Pada prinsipnya Equality Before The Law adalah tidak ada tempat bagi backing yang salah, melainkan undang-undang merupakan backine terhadap yang benar.

3.Constitution Based On Human Rights

Human Right, meliputi 3 hal pokok, yaitu:

a) The rights to personal freedom ( kemerdekaan pribadi), yaitu hak untuk melakukan sesuauatu yang dianggap baik badi dirinya, tanpa merugikan orang lain.

b) The rights to freedom of dis cussion ( kemerdekaan berdiskusi), yaitu hak untuk mengemukakan pendapat dan mengkritik, dengan ketentuan yang bersangkutan juga harus bersedia mendengarkan orang lain dan bersedia menerima kritikan orang lain.

c) The Rights To P ublic Meeting (kemerdekaan mengadakan rapat), kebebasan ini harus dibatasi jangan sampai menimbulkan kekacauan atau memprovokasi. 
Dari paham ini merupakan kelanjutan dari ajaran john locke yang berpendapat bahwa:

-Manusia sejakk lahir sudah mempunyai hak - hak asasi manusia.

-Tidak seluruh hak - hak asasi manusia diserahka kepada negara dalam kontrak social.

Persaamaan negara hukum eropa continental dengan negara hukum anglos axon adalah keduanya mengakui adanya "Supremasi H ukum". Perbedaannya adalah negara anglos axon tidak terdapat peradilan administrasi yang berdiri sendiri sehingga siapa saja yang melakukan pelanggaran akan diadili pada peradilan yang sama.sedangkan negara hukum eropa continental terdapat peradilan administasi yang berdiri sendiri.

Ciri sistem Anglo- S axon adalah suatu sistem hukum yang didasarkan pada yuris prudensi, yaitu keputusan-keputusan hakim terdahulu yang kemudian menjadi dasar putusan hakim- hakim selanjutnya sistem hukum ini diterapkan di Irlandia, Inggris, Australia, Selandia Baru, Afrika Selatan, Kanada (kecuali Provinsi Quebec) dan Amerika Serikat (walaupun negara bagian Louisiana mempergunakan sistem hukum ini bersamaan dengan sistem hukum Eropa Kontinental Napoleon). Selain negara- negara tersebut, beberapa negara lain juga menerapkan sistem hukum Anglo- $\mathrm{S}$ axon campuran, misalnya Pakis tan, India dan Nigeria yang menerapkan sebagian besar sistem hukum Anglo-S axon, namun juga memberakukan hukum adat dan hukum agama. Sistem hukum anglo s axon, sebenarnya penerapannya lebih mudah 
Terutama pada masyarakat pada negara- negara berkembang karena sesuai dengan perkembangan zaman.p endapat para ahli dan prakitis hukum lebih menonjol digunakan oleh hakim, dalam memutus perkara

di Tipe Negara Kemakmuran (Wohlfare Staat)

Pada tipe Negara kemakmuran atau wohlfare s taat ini, $\mathrm{N}$ egara mengabdi sepenuhnya kepada mas yarakat. Dalam Negara kemakmuran maka Negara adalah alat satu - satunya untuk menyelenggar akan kemakmuran warganya, untuk kepentingan seluruh rakyat dan Negara. Jadi pada Negara kemakmuran ini tugas daripada Negara adalah semata -mata menyelenggar akan kemakmuran rakyat yang semaksimal mungkin.

Sebuah negara kesejahteraan adalah konsep "pemerintahan di mana negara memainkan peran kunci dalam perlindungan dan promosi ekonomi dan kesejahteraan sosial warganya. Hal ini didasarkan pada prinsip- prinsip persamaan kesempatan, distribusi kekayaan yang adil, dan tanggung jawab publik untuk mereka yang tidak mampu untuk memanfaatkan diri dari ketentuan minimal untuk kehidupan yang baik. istilah umum dapat mencakup berbagai bentuk organisasi ekonomi dan sosial “.

Negara kesejahteraan modern termasuk negara- negara seperti Swedia, Norwegia, Denmark dan Finlandia yang mempekerjakan suatu sistem yang dikenal sebagai model Nordik. Negara kesejahteraan melibatkan transfer langsung dana dari negara, dengan layanan yang diberikan (yaitu kesehatan, pendidikan) serta langsung kepada individu ("manfaat"). Negara kesejahteraan ini 
didanai melalui pajak redistribusionis dan sering disebut sebagai jenis "ekonomi campuran" di Amerika Serikat dan banyak negara lainnya.

a)Etimologi (asal- usul kata atau makna)

Istilah Jerman (Sozials taat, "negara sosial") telah digunakan sejak 1870 untuk menggambarkan program- program dukungan negara sedang dikembangkan oleh Sozialpolitiker- "Politisi Sosial" Jerman - dan dilaksanakan melalui reformasi konservatif Bismarck. Meskipun upaya awal untuk menggunakan frase setara dalam bahasa Inggris istilah hanya masuk umum digunakan ketika William Temple dipopulerkan selama Perang Dunia Kedua, negara kesejahteraan kontras perang Inggris dengan "keadaan perang" dari Nazi Jerman. Istilah Italia "negara Sosial" (Stato Sociale) memiliki asal yang sama. Negara kesejahteraan Swedia disebut Folkhemmet (harfiah; rumah rakyat) dan kembali ke kompromi 1936 antara Uni dan perusahaan Korporasi besar. Ini adalah ekonomi campuran, dibangun di atas serikat pekerja yang kuat dan sistem keamanan yang kuat Sosial dan perawatan keehatan universal. Istilah "Wohlfahrts staat", terjemahan langsung dari bahasa Inggris, digunakan di Jerman untuk menggambarkan Swedia.

Dalam bahasa Spanyol dan banyak lainnya, istilah analog digunakan: Estado del bienestar; diterjemahkan secara harfiah: “negara kesejahteraan”. Dalam bahasa Portugis, dua frase serupa ada: "Estado melakukan bem- Estar SoCal" yang berarti "negara keejahteraan sosial" dan de Estado Providencia yang berarti 
"Negara Menyediakan", seperti dalam Negara harus menyediakan warga tuntutan mereka dalam rangka mencapai masyarakat kesejahteraan. Di Brasil ini disebut ebagai Previdencia Sosial, diterjemahkan sebagai sosial pemeliharaan.

b)Sejarah Negara - Negara kesejahteraan

\section{Jerman}

Di Jerman, Kanelir Otto von Bis marck menciptakan negara kesejahteraan modern dengan membangun tradisi program kesejahteraan di Prusia dan Saxony yang dimulai sejak tahun 1840an, dan dengan memenangkan dukungan dari bisnis. Pada tahun 1880-an ia memperkenalkan pensiun usia tua, asuransi kecelakaan,

perawatan medis dan auransi pengangguran yang membentuk dasar negara kesejahteraan modern Eropa. Program paternal istik memenangkan dukungan dari industri Jerman karena tujuannya adalah untuk memenangkan dukungan dari kelas pekerja untuk Kekaisaran dan mengurangi arus imigran ke Amerika, dimana upah lebih tinggi tetapi kesejahteraan tidak ada. Bismarck lanjut memenangkan dukungan dari kedua industri dan pekerja terampil dengan kebijakan tarif yang tinggi, yang melindungi keuntungan dan upah dari persaingan Amerika, meskipun mereka terasing para intelektual liberal yang menginginkan perdagangan bebas . Program- program kesejahteraan modern berbeda dari skema sebelumnya bantuan kemiskinan karena jangkauan mereka relatif universal. Perkembangan asuransi sosial di Jerman di bawah 1880-an ia memperkenalkan pensiun usia tua, asuransi kecelakaan, 
perawatan medis dan asuransi pengangguran yang membentuk dasar negara kesejahteraan modern Eropa. Program paternalistik memenangkan dukungan dari industri Jerman karena tujuannya adalah untuk memenangkan dukungan dari kelas pekerja untuk Kekaisaran dan mengurangi arus imigran ke Amerika, di mana upah lebih tinggi tetapi kesejahteraan tidak ada. Bismarck lanjut memenangkan dukungan dari kedua industri dan pekerja terampil dengan kebijakan tarif yang tinggi, yang melindungi keuntungan dan upah dari persaingan Amerika, meskipun mereka terasing para intelek tual liberal yang menginginkan perdagangan bebas . Program- program kesejahteraan modern berbeda dari skema sebelumnya bantuan kemiskinan karena jangkauan mereka relatif universal. Perkembangan asuransi sosial di Jerman di bawah Bismarck sangat berpengaruh. Beberapa skema sebagian besar didasarkan pada pengembangan otonom, penyediaan mutualis manfaat. Lainnya didirikan pada penyediaan negara. Istilah ini tidak, bagaimanapun, diterapkan untuk semua negara yang menawarkan perlindungan sosial. Para sosiologi T.H . Marshall mengidentifikasi negara kesejahteraan sebagai kombinasi khas dari demokrasi, kesejahteraan dan kapitalisme. Contoh awal negara kesejahteraan di dunia modern adalah Jerman, semua Negara Nordik, Belanda, Uruguay dan Selandia Baru dan Inggris pada 1930an.Sikap berubah dalam reaksi terhadap Depresi Besar berperan di pindah ke negara kesejahteraan di banyak negara, pertanda kali baru dimana "cradle- to-kuburan" layanan menjadi kenyataan setelah 
Depresi kemiskinan. Selama depresi Besar, terlihat sebagai sebuah "jalan tengah" alternatif antara komunisme dan kapitalisme Pada periode setelah Perang Dunia Kedua., Banyak negara di Eropa pindah dari penyediaan parsial atau selektif pelayanan sosial untuk cakupan yang relatif komprehensif populasi.

kegiatan masa kini negara kesejahteraan meluas kepemberian bantuan tunai kesejahteraan (seperti pensiun hari tua atau tunjangan pengangguran) dan pelayanan kesejahteraan dalam bentuk (seperti kesehatan atau pelayanan perawatan anak). Melalui ketentuan ini, negara kesejahteraan dapat mempengaruhi distribusi kesejahteraan dan otonomi pribadi antara warga negara mereka, serta mempengaruhi bagaimana warga negara mereka mengkonsumsi dan bagaimana mereka menghabiskan waktu mereka

\section{Inggris}

D i Inggris , awal negara kesejahteraan modern pada tahun 1911 saat David Lloyd George dan P artai Liberal mengesahkan UndangUndang Asuransi nasional 1911 mendirikan kontribusi asuransi nasional untuk tunjangan pengangguran dan kesehatan kerja. Pada tahun 1942, Asuransi Sosial dan Layanan Sekutu diciptakan oleh Sir William Beveridge dalam rangka untuk membantu mereka yang membutuhkan bantuan, atau dalam kemis kinan. Beveridge bekerja suka relawan untuk orang miskin, dan mendirikan asuransi nasional Dia menyatakan bahwa 'Semua orang usia kerja harus membayar 
kontribusi asuransi mingguan nasional. Sebagai imbalannya, manfaat akan dibayarkan kepada orang yang sakit, menganggur, pensiun atau janda. asumsi dasar laporan itu bahwa $\mathrm{N}$ ational health Service akan menyediakan perawatan kesehatan gratis untuk semua warga negara. Manfaat Anak universal adalah skema untuk memberikan manfaat kepada orang tua, mendorong orang untuk memiliki anak dengan memungkinkan mereka untuk memberi makan dan mendukung keluarga. Salah satu tema laporan adalah relatif murahnya manfaat universal.

Beveridge dikutip skema pensiun penambang sebagai beberapa yang paling efisien yang tersedia, dan berpendapat bahwas kema negara akan lebih murah untuk menjalankan dari masyarakat yang ramah individu dan skema asuransi swasta, serta menjadi lebih murah daripada cara- diuji dikelola pemerintah skema bagi masyarakat miskin.Murahnya dari apa yang disebut Asuransi Nasional merupakan argumen bersama keadilan, dan dibenarkan skema di mana orang kaya disetor dan negara dibayarkan- out untuk orang kaya, seperti bagi kaum miskin.

Dalam skema asli, hanya beberapa manfaat yang disebut Bantuan nasional itu harus dibayar terlepas dari kontribusi. Universal manfaat dibayarkan kepada kaya dan miskin seperti tunjangan anak yang sangat menguntungkan setelah Perang Dunia Kedua ketika tingkat kelahiran rendah. anak Manfaat Universal mungkin telah membantu mendorong booming Bayi Dia menyatakan bah a 'Semua orang usia kerja harus membayar 
kontribusi asuransi mingguan nasional. sebagai imbalannya, manfaat akan dibayarkan kepada orang yang sakit, menganggur, pensiun atau janda. Asumsi dasar laporan itu bahwa National Health Service akan menyediakan perawatan kesehatan gratis untuk semua warga negara. manfaat anak Universal adalah skema untuk memberikan manfaat kepada orang tua, mendorong orang untuk memiliki anak dengan memungkinkan mereka untuk memberi makan dan mendukung keluarga. Salah satu tema laporan adalah relatif murahnya manfaat universal.

Beveridge dikutip skema pensiun penambang sebagai beberapa yang paling efisien yang tersedia, dan berpendapat bahwa skema negara akan lebih murah untuk menjalankan dari masyarakat yang ramah individu dan skema asuransi swasta, serta menjadi lebih murah dari pada cara- diuji dikelola pemerintah skema bagi masyarakat miskin.Murahnya dari apa yang disebut Asuransi Nasional merupakan argumen bersama keadilan, dan dibenarkan skema di mana orang kaya disetor dan negara dibayarkan- out untuk orang kaya, eperti bagi kaum miskin.

Dalam skema asli, hanya beberapa manfaat yang diebut Bantuan Nasional itu harus dibayar terlepas dari kontribusi. Universal manfaat dibayarkan kepada kaya dan miskin seperti tunjangan anak yang sangat menguntungkan setelah perang dunia kedua ketika tingkat kelahiran rendah. anak manfaat univers al mungkin telah membantu mendorong booming Bayi. Beveridge merekomendasikan kepada pemerintah bahwa mereka 
harus menemukan cara untuk mengatasi lima raksaksa, sedang Ingin, Penyakit, Ketidaktahuan, Squalor dan kemalasan. Dia berargumen untuk menyembuhkan masalah ini, pemerintah harus memberikan penghasilan yang memadai kepada orang-orang, perawatan kesehatan yang memadai, pendidikan yang memadai, perumahan yang layak dan pekerjaan yang memadai. Sebelum 1939, perawatan kesehatan yang paling harus dibayar melalui organisasi non pemerintah, ini dilakukan melalui jaringan yang luas dari masyarakat yang ramah, serikat pekerja dan perusahaan asuransi lain yang menghitung sebagian besar penduduk yang bekerja di Inggris sebagai anggota. Masyarakat yang ramah ini menyediakan asuransi untuk penyakit, pengangguran dan cacat, sehingga memberikan orang dengan penghasilan ketika mereka tidak mampu bekerja. Tetapi karena tahun 1942 Laporan Beveridge, dalam 5 J uli 1948, UU Asuransi Nasional, Nasional Bantuan Act dan UU Pelayanan Kesehatan Nasional diberlakukan, sehingga ini adalah hari bahwa negara kesejahteraan modern Inggris didirikan. Lembaga dijalankan oleh dewan lokal untuk menyediakan layanan kesehatan bagi masyarakat miskin diasuransikan - bagian dari tradisi hukum miskin workhouses - digabung ke dalam system nasional baru. kesejahteraan sistem telah berkembang intensif sejak akhir Perang Dunia II. Pada akhir abad karena restrukturisasi mereka, bagian dari tanggung jawab mereka mulai disalurkan melalui organisasi nonpemerintah yang menjadi penyedia penting dari layanan sosial.

3. Negara Minyak 
Arab Saudi, Brunei, kuwait, Qatar, Bahrain, oman, dan Uni Emirat Arab menjadi negara-negara kesejahteraan semua warga negara mereka, tetapi tidak untuk warga negara asing secara hukum penduduk atau dipekerjakan.

\section{PENUTUP}

3. Kesimpulan

Tipe negara ialah s uatu penggolongan negara yang tidak mempunyai batas -batas yang tegas. Ini berbeda dengan klas ifikas i negara atas bentuk-bentuk tertentu, misal bentuk negara (Kesatuan atau federasi) dan bentuk pemerintahan (Kerajaan atau Republik) dimana batas - batas dan ukurannya cukup tegas sehingga mudah dikenali. Menurut Prof. Logemann, tipe negara lebih berkenaan dengan struktur batin pemerintah, mengenai hubungan antara pemerintah dengan warga negara, dan mengenai tugas negara. Tipe negara ditinjau dari segi sejarah antara lain :

a)Tipe negara- negara yunani kuno, yang ciri-cirinya : merupakan polis (city state) dan demokratis (langsung).Tipe Negara ditinjau dari sisi hokum antara lain :

a) Negara Polisi (polizei Staat), cirinya : - Negara menentukan segalanya, sedang rakyat pasif (jadi siofat hubungan negara/penguasa rakyat adalah "Positif- Pasif" • Solus Publica Supreme lex, artinya kepentingan umum diatas segalanya, termasuk diatas hukum/undang- undang - Principe legibus solutusest, artinya hanya raja/penguasa yang dapat membuat 
hukum/undang- undang • Dipengaruhi aliran merkantilisme dalam ilmu ekonomi.

b) Negara Hukum Formal/ Liberal (Formeele. Liberal Rechtstaat) Negera hukum formal merupakan antitesis dari negara polisi, cirinya : - Negara tak boleh campur tangan dalam bidang ekonomi, rakyat yang bebas atau aktif dalam pemerint ahan, sehingga status hubungan negara- rakyat sifatnya negatif-aktif • Negara hanya merupakan wasit saja kalau ada pelanggaran aturan permainan dari rakyat yang berkompetisi bebas, sehingga disebut juga "negara Penjaga malam" • Pandangan akan hukum yang sempit (undang-undang) dan aliran liberailsme sangat mempengaruhi tipe negara hukum formil ini. Negara Hukum Materiil/Modern atau negara Kesejahteraan(welfare state).

c) Tipe negara hukum materiil merupakan tesis baru dari negara polisi (tesis ) dan negara hukum formal(antitesis). Sifat hubungan negara- rakyat adalah positif- aktif

\section{v DAFTAR PUSTAKA}

Darmini Roza dan Laurensius Arliman S, Peran Pemerintah Daerah Di Dalam Melindungi Hak Anak Di Indonesia, Masalah-Masalah Hukum, Volume 47, Nomor 1, 2018. https://doi.org/10.14710/mmh.47.1.2018.10-21

Laurensius Arliman S, Peranan Metodologi Penelitian Hukum di Dalam Perkembangan Ilmu Hukum di Indonesia, Soumatera Law Review, Volume 1, Nomor 1, 201. http://doi.org/10.22216/soumlaw.v1i1.3346.

Laurensius Arliman S, Peran Badan Permusyawaratan Desa di Dalam Pembangunan Desa dan Pengawasan Keuangan Desa, Padjadjaran Journal of Law, Volume 4, Nomor 3, 2017. https://doi.org/10.15408/jch.v4i2.3433.

Laurensius Arliman S, Penanaman Modal Asing Di Sumatera Barat Berdasarkan Undang- Undang Nomor 25 Tahun 2007 Tentang Penanaman Modal, Supremasi Hukum, Volume 1, Nomor 1, 2018. http://dx.doi.org/10.36441/hukum.v1i01.102 . 
Laurensius Arliman S, Memperkuat Kearifan Lokal Untuk Menangkal Intoleransi UmatBeragama Di Indonesia, Ensiklopedia of Journal, Volume 1, Nomor 1, 2018, https://doi.org/10.33559/eoj.v1i1.18.

Laurensius Arliman S, Perkawinan Antar Negara Di Indonesia Berdasarkan Hukum Perdata Internasional, Kertha Patrika, Volume 39, Nomor 3, 2017, https://doi.org/10.24843/KP.2017.v39.i03.p03.

Laurensius Arliman S, Partisipasi Masyarakat Di Dalam Pengelolaan Uang Desa Pasca UndangUndang Nomor 6 Tahun 2014 Tentang Desa, Jurnal Arena Hukum, Volume 12, Nomor 2, 2019, https://doi.org/10.21776/ub.arenahukum.2019.01202.5.

Laurensius Arliman S, Mewujudkan Penegakan Hukum Yang Baik Di Negara Hukum Indonesia, Dialogica Jurnalica, Volume 11, Nomor 1, 2019, https://doi.org/10.28932/di.v11i1.1831.

Laurensius Arliman S, Mediasi Melalui Pendekatan Mufakat Sebagai Lembaga Alternatif Penyelesaian Sengketa Untuk Mendukung Pembangunan Ekonomi Nasional, UIR Law Review, Volume 2, Nomor 2, 2018, https://doi.org/10.25299/uirlrev.2018.vol2(02).1587

Laurensius Arliman S, Peranan Filsafat Hukum Dalam Perlindungan Hak Anak Yang Berkelanjutan Sebagai Bagian Dari Hak Asasi Manusia, Doctrinal, Volume 1, Nomor 2,2016.

Laurensius Arliman S, Ni Putu Eka Dewi, Protection of Children and Women's Rights in Indonesia through International Regulation Ratification, Journal of Innovation, Creativity and Change Volume 15, Nomor 6, 2021.

Laurensius Arliman S, Gagalnya Perlindungan Anak Sebagai Salah Satu Bagian Dari Hak Asasi Manusia Oleh Orang Tua Ditinjau Dari Mazhab Utilitarianisme, Jurnal Yuridis, Volume 3, Nomor 2, 2016, http://dx.doi.org/10.35586/.v3i2.180.

Laurensius Arliman S, Tantangan Pendidikan Kewarganegaraan Pada Revolusi 4.0, Jurnal Ensiklopedia Sosial Review, Volume 2, Nomor 3, $2020 .$. 